\title{
PENGARUH KUALITAS PRODUK, GAYA HIDUP, DAN PENGETAHUAN PRODUK TERHADAP PROSES KEPUTUSAN PEMBELIAN SEPEDA LIPAT DI KOTA SEMARANG
}

\author{
Yusuf Bagus Prakosa \\ Fakultas Ekonomika dan Bisnis, Universitas Stikubank Semarang \\ Endang Tjahjaningsih* \\ Fakultas Ekonomika dan Bisnis, Universitas Stikubank Semarang \\ *naning@edu.unisbank.ac.id
}

\begin{abstract}
This study aims to analyze the effect of product quality on the purchasing decision process, the influence of lifestyle on the purchasing decision process and the influence of product knowledge on the folding bicycle purchase decision process in Semarang City. This research was conducted from November to December 2020 with the number of samples used as many as 100 respondents with the sampling technique in this study was purposive sampling. The data analysis technique used instrument test, model test, regression test using SPSS 24.0 software. The results showed that product quality, lifestyle, and product knowledge had a positive effect on the purchasing decision process. Product quality has the greatest influence on the purchasing decision process compared to lifestyle and product knowledge. The better the quality of the product, the higher the purchasing decision process.
\end{abstract}

Keywords: Product Quality, Lifestyle, Product Knowledge and Purchasing Decision Process

\section{Pendahuluan}

Seiring berkembangnya jaman sepeda tidak hanya sebagai alat transportasi saja, namun sepeda sudah menjadi hobi dan gaya hidup bagi sebagian orang di Indonesia. Di masa new normal saat ini sepeda kembali digemari oleh masyarakat Indonesia. Penggemar sepeda dari berbagai kalangan usia mulai dari anak-anak, hingga dewasa. Berdasarkan fenomena tersebut, masyarakat memutuskan untuk membeli dan menggunakan sepeda karena selain untuk berolah raga, sebagai alternatif mengilangkan kebosanan menjalani work from home (WFH) dan learn from home $(L F H)$. Selain itu, juga terdapat banyak komunitas-komunitas sepeda yang baru terbentuk karena tren sepeda saat ini. Berdasarkan riset yang dilakukan situs meta-search iPrice maka jenis sepeda yang saat ini beredar di pasar Indonesia antara lain, sepeda lipat (folding bike), MTB, Fixie, Road Bike, City Bike, dan sepeda anak.

Dari berbagai jenis sepeda yang beredar di pasar Indonesia, terdapat 3 (tiga) jenis sepeda yang paling dicari oleh konsumen Indonesia. Sepeda lipat, sepeda gunung dan sepeda anak menjadi 3 (tiga) model dari beberapa model sepeda yang menjadi tren di Indonesia. Sepeda lipat adalah yang paling banyak diminati. Search interest di Google Trends untuk sepeda lipat naik mencapai 900\% sejak 1 Maret hingga 21 Juni 2020. Pada urutan selanjutnya, sepeda gunung (MTB) terjadi kenaikan search interest mencapai 680\% sejak 1 Maret hingga 
21 Juni 2020. Peringkat ketiga yaitu sepeda anak dengan pencarian yang juga mengalami kenaikan sejak 1 Maret. tetapi, kenaikan tidak begitu signifikan yaitu hanya $142 \%$. Peringkat terakhir Road bike atau sepeda balap dengan kenaikan pencarian sebesar $300 \%$ selama periode yang sama. Hasil search interest ini berbanding lurus dengan fakta lapangan bahwa $60 \%$ dari pasar saat ini lebih memilih sepeda lipat, 30\% untuk pasar sepeda gunung (MTB), sedangkan sisanya $10 \%$ merupakan jenis lain seperti sepeda kota dan sepeda untuk anak-anak. (www.https://iprice.co.id/). Beragam jenis sepeda yang digunakan warga Kota Semarang, antara lain, sepeda lipat (folding bike), MTB, Fixie, Road Bike. Namun sepeda lipat lebih populer dan diminati daripada sepeda jenis lain. sepeda lipat memiliki keunggulan fitur yang tidak dimiliki oleh sepeda jenis lainya. Fitur utama yang dimiliki adalah sepeda folding bike dapat dilipat menjadi ukuran yang lebih ringkas untuk memudahkan penggunanya dalam membawa kemanapun dan menyimpanya di ruang yang terbatas.

Tabel 1. Data Top Brand Award Sepeda Lipat Tahun 2019-2020

\begin{tabular}{|l|l|l|}
\hline Merek & Tahun 2019 & Tahun 2020 \\
\hline Polygon & $24,9 \%$ & $37,5 \%$ \\
\hline United & $16.6 \%$ & $17.0 \%$ \\
\hline Delta & $12,9 \%$ & $13.5 \%$ \\
\hline
\end{tabular}

Sumber: www.topbrand-award.com

Berdasarkan Tabel 1 terlihat bahwa sepeda lipat merek Polygon menjadi pemimpin pasar dalam sepeda lipat (folding bike), yang diikuti oleh merek United dan Delta. Berbagai merek sepeda lipat dengan berbagai model dan keunggulan tentu menjadi pertimbangan konsumen dalam membeli sepeda lipat (folding bike) sesuai dengan keinginan. Meningkatnya daya beli konsumen ditengah pandemi terhadap sepeda tidak terlepas dari kualitas produk yang semakin meningkat, pola gaya hidup konsumen dan pengetahuan terhadap suatu produk yang dimiliki konsumen sebelum mementukan keputusan pembelian. Kualitas produk merupakan hal penting yang harus diusahakan oleh setiap perusahaan apabila menginginkan produk yang dihasilkan dapat bersaing di pasar. Konsumen memiliki pertimbangan sebelum membeli produk, dan banyak faktor yang mempengaruhi konsumen untuk menentukan keputusan pembelian suatu produk. Adanya hubungan erat antara perusahaan dengan konsumen akan memberikan peluang untuk mengetahui dan memahami apa yang menjadi kebutuhan dan harapan yang ada pada persepsi konsumen.

Dari beberapa penelitian terdahulu variabel kualitas produk berdasarkan penelitian Sari dkk (2018), Dewi dan Rokh Eddy (2018) menyatakan bahwa kualitas produk memiliki pengaruh positif dan signifikan terhadap keputusan pembelian karena semakin baik kualitas produk, akan semakin meningkatkan keputusan pembelian. Begitu pula sebaliknya semakin rendah kualitas produk, akan menurunkan keputusan pembelian. Penelitian dilakukan oleh Sisilia dkk (2015), Wifky dan Soliha (2017) menyatakan kualitas produk berpengaruh signifikan terhadap keputusan kembelian, sedangkan Nadwatul dkk (2019), Usman dan Galih (2019) menyatakan kualitas produk berpengaruh negatif terhadap keputusan pembelian. Disamping kualitas produk, gaya hidup merupakan salah satu faktor yang mempengaruhi keputusan pembelian konsumen terhadap suatu produk. Konsumen mengharapkan untuk membeli produk yang dapat menunjang kebutuhannya. Gaya hidup yang berubah mengakibatkan perubahan terhadap selera masing-masing individu. Sehingga untuk pemilihan jenis sepeda pun menyesuaikan dengan gaya hidupnya. Konsumen yang memutuskan untuk membeli sepeda jenis lipat umumnya digunakan masyarakat perkotaan sebagai penunjang kegiatan konusmen baik untuk berolah raga mauapun alat transportasi yang menyehatkan. 
Penelitian oleh Mokoagouw (2016) dan Estu (2018) menghasilkan penelitian bahwa gaya hidup mempunyai pengaruh positif terhadap keputusan pembelian. Namun penelitian Sisilia dkk (2015) menghasilkan penelitian bahwa gaya hidup tidak mempunyai pengaruh signifikan terhadap keputusan pembelian. Konsumen yang mempunyai pengetahuan produk memiliki ingatan untuk pengenalan, analisa dan kemampuan logis yang lebih baik daripada konsumen yang kurang dalam pengetahuan produk, sehingga konsumen yang berfikir bahwa mereka memiliki pengetahuan produk yang lebih baik akan memgandalkan pada petunjuk intrinsik untuk membandingkan kualitas produk karena konsumen sadar pentingnya informasi suatu produk. Penelitian yang dilakukan oleh Khosrozadeh dan Heidarzadeh (2011), Novizal dan Rizal (2020), mengemukakan bahwa pengetahuan produk konsumen berpengaruh positif dan signifikan terhadap keputusan pembelian. Sedangkan penelitian yang dilakukan oleh Yoesmanam (2015) mengemukakan bahwa pengetahuan produk berpengaruh positif terhadap keputusan pembelian. Dari penelitian tersebut menunjukan bahwa semakin baik pengetahuan produk konsumen, maka semakin tinggi pula keputusan pembelian terhadap suatu produk.

Berdasarkan fenomena bisnis dan perbedaaan hasil penelitian, maka rumusan masalah disusun sebagai berikut:

1. Apakah kualitas produk berpengaruh terhadap proses keputusan pembelian sepeda lipat di Kota Semarang?

2. Apakah gaya hidup berpengaruh terhadap proses keputusan pembelian sepeda lipat di Kota Semarang?

3. Apakah pengetahuan produk berpengaruh terhadap proses keputusan pembelian sepeda lipat di Kota Semarang?

Penelitian ini bertujuan sebagai berikut :

1. Untuk menganalisis pengaruh kualitas produk terhadap proses keputusan pembelian sepeda lipat di Kota Semarang.

2. Untuk menganalisis pengaruh gaya hidup terhadap proses keputusan pembelian sepeda lipat di Kota Semarang.

3. Untuk menganalisis pengaruh pengetahuan produk terhadap proses keputusan pembelian sepeda lipat di Kota Semarang.

\section{Landasan Teori dan Pengembangan Hipotesis}

\section{Proses Pengambilan Keputusan}

Kotler dan Keller (2016) menjelaskan keputusan pembelian sebagai proses psikologis dasar memainkan peran penting dalam memahami bagaimana konsumen benar-benar membuat keputusan pembelian mereka. Dalam proses pembelian terdapat lima tahap yang dilalui konsumen, yaitu pengenalan kebutuhan, pencarian informasi, evaluasi alternatif, keputusan pembelian dan perilaku pasca pembelian.

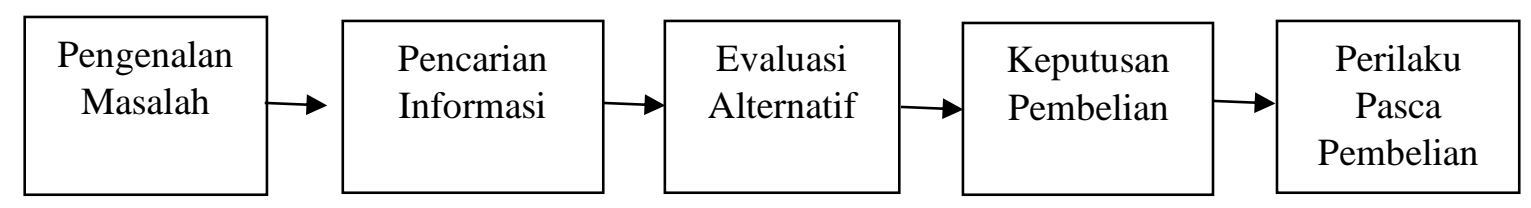

Gambar 1. Tahap-tahap Proses Pengambilan Keputusan

Sumber : Kotler dan Keller (2016) 
Dari gambar 1 tersebut dapat dijelaskan sebagai berikut :

1. Pengenalan masalah

Proses pengambilan kebutuhan dimulai saat pembeli mengenali sebuah masalah atau kebutuhan. Pemasar perlu mengidentifikasi keadaan apa yang memicu kebutuhan dengan mengumpulkan informasi tertentu melalui konsumen, pemasar dapat mengidentifikasi rangsangan intersnal atau eksternal yang paling sering memotivasi konsumen.

2. Pencarian Informasi

Konsumen yang tergugah kebutuhannya akan terdorong untuk mencari informasi yang lebih banyak. Untuk mendapatkan sumber informasi itu berbeda-beda tergantung pada produk dan karakteristiknya. Konsumen dapat menperoleh informasi dari berbagai sumber. Sumber-sumber ini meliputi:

a. Sumber pribadi : Keluarga, teman, dan tetangga.

b. Sumber komersial : Iklan, wiraniaga, situs web, penyalur, kemasan, tampilan.

c. Sumber publik : Media massa, organisasi pemeringatan konsumen, pencarian internet.

d. Sumber pengalaman : Penanganan, pemeriksaan, dan pemakaian produk.

3. Evaluasi alternatif

Pada tahap ini konsumen menggunakan informasi untuk sampai pada sejumlah pilihan merek akhir. Evaluasi alternatif yaitu bagaimana konsumen memproses informasi untuk sampai pada pilihan merek.

4. Keputusan pembelian

Tahap keputusan pembelian dipengaruhi oleh dua faktor umum, yang pertama sikap orang lain. Hal ini membuat konsumen mempertimbangkan tingkat sikap negatif orang lain terhadap alternatif pilihannya, serta motivasi konsumen untuk mengiyakan alternatif orang lain tersebut. Sementara itu faktor yang kedua adalah kondisi dimana keadaan yang tidak diduga serta memiliki resiko terhadap alternatif keputusan tersebut. Hal ini menjadikan konsumen mempertimbangkan ulang alternatif yang sebenarnya ingin diputuskan.

5. Perilaku pasca pembelian

Perilaku pascapembelian memungkinkan konsumen membeli kembali sebuah produk apabila merasa puas. Sebaliknya, apabila konsumen kecewa maka konsumen akan berhenti membeli kembali produk dengan merek yang sama. Konsumen juga cenderung akan menceritakan pengalamannya baik positif maupun negatif setelah ia mengkonsumsi produk tersebut kepada orang lain. Elemen terpenting perilaku konsumen adalah proses pengambilan keputusan dalam pembelian. Dalam mempelajari perilaku konsumen dapat dilakukan melalui variabel-variabel lain yaitu pendekatan "black box theory" dimana terdapat rangsangan yang kemudian masuk dan diolah untuk menghasilkan keputusan pembelian.

\begin{tabular}{|c|c|c|c|c|}
\hline \multirow{3}{*}{$\begin{array}{l}\text { Rangsangan } \\
\text { Pemasaran }\end{array}$} & \multirow{3}{*}{$\begin{array}{l}\text { Rangsangan } \\
\text { Lain }\end{array}$} & \multirow{2}{*}{\multicolumn{2}{|c|}{ Kotak hitam }} & \\
\hline & & & & \multirow{5}{*}{$\begin{array}{l}\text { Keputusan Pembelian } \\
\text { Pilihan produk } \\
\text { Pilihan merek } \\
\text { Pilihan pemasok } \\
\text { Pilihan saat pembelian } \\
\text { Jumlah pembelian }\end{array}$} \\
\hline & & $\begin{array}{l}\text { Karakter } \\
\text { Pembelian }\end{array}$ & $\begin{array}{l}\text { Proses keputusan } \\
\text { pembelian }\end{array}$ & \\
\hline \multirow{3}{*}{$\begin{array}{l}\text { Produk } \\
\text { Harga } \\
\text { Tempat } \\
\text { Promosi }\end{array}$} & \multirow{4}{*}{$\begin{array}{l}\text { Ekonomi } \\
\text { Teknologi } \\
\text { Politik } \\
\text { Budaya } \\
\end{array}$} & Budaya & Pengenalan masalah & \\
\hline & & Sosial & Pencarian informasi & \\
\hline & & Pribadi & Evaluasi alternatif & \\
\hline & & Psikologi & $\begin{array}{l}\text { Perilaku pasca } \\
\text { pembelian }\end{array}$ & \\
\hline
\end{tabular}

Gambar 2. Model Perilaku Pembelian

Sumber : Kotler dan Keller (2016) 
Berdasarkan model perilaku konsumen seperti pada gambar 2 menunjukan rangsangan antara pemasaran dan lainya yang masuk dalam kotak hitam pembelian dan menghasilkan tanggapan pembeli. Rangsangan pemasaran yang tergambar dalam kotak hitam bagian kiri terdiri dari dua jenis, yaitu :

1. Rangsangan pemasaran yang terdiri dari $4 \mathrm{P}$ yaitu produk (product), harga (price), tempat (place), promosi (promotion).

2. Rangsangan lingkungan yang terdiri dari ekonomi, teknologi, politik, dan kebudayaan.

\section{Faktor Proses Keputusan Pembelian}

Faktor-faktor yang mempengaruhi keputusan pembelian menurut Kotler dan Amstrong (2014) terdapat empat faktor yang mempegaruhi perilaku konsumen dalam memutuskan untuk melakukan pembelian, yaitu :

1. Faktor Budaya

Budaya, sub budaya, dan kelas sosial sangat penting bagi perilaku pembelian. Budaya merupakan penentu keinginan dan perilaku paling dasar. Tumbuh di dalam suatu masyarakat seseorang anak mempelajari nilai-nilai dasar, persepsi, keinginan, dan perilaku yang dipelajari anggota suatu masyarakat dari keluarga dan yang lainya.

2. Faktor Sosial

Perilaku konsumen juga dipengaruhi oleh faktor social seperti kelompok acuan, keluarga, serta peran dan status.

3. Faktor Pribadi

Keputusan pembelian juga dipengaruhi oleh karakteristik pribadi diantaranya usia dan tahap siklus hidup, pekerjaan, keadaan ekonomi, gaya hidup, kepribadian dan konsep diri pembeli.

4. Faktor Psikologis

a. Motivasi, seseorang memiliki banyak kebutuhan pada waktu tertentu. Beberapa dari kebutuhan tersebut ada yang muncul dari tekanan biologis seperti lapar, haus dan rasa ketidaknyamanan. Sedangkan beberapa kebutuhan yang lainnya dapat bersifat psikogenesis yaitu kebutuhan yang berasal dari tekanan psikologis seperti kebutuhan akan pengakuan, penghargaan atau rasa keanggotaan kelompok.

b. Persepsi, dapat diartikan sebuah proses yang digunakan individu untuk memilih, mengorganisasi, dan menginterpretasi masukan informasi guna menciptakan sebuah gambaran. Persepsi tidak hanya bergantung pada rangsangan fisik tetapi juga pada rangsangan yang berhubungan dengan lingkungan sekitar dan keadaan individu yang bersangkutan.

\section{Kualitas Produk}

Kotler dan Armstrong (2014) menjelasakn kualitas produk merupakan kemampuan produk untuk menunjukkan berbagai fungsi termasuk di dalamnya ketahanan, kehandalan, ketepatan, dan kemudahan dalam penggunaan. Menurut Kotler dan Keller (2016) kualitas produk adalah totalitas fitur dan karakteristik produk atau jasa yang bergantung pada kemampuannya untuk memuaskan kebutuhan konsumen yang dinyatakan atau tersirat. Untuk memuaskan konsumen serta untuk meningkatkan penjualan perusahaan harus memperhatikan kualitas produk, karena sebelum membeli sebuah produk, tentu konsumen akan memilih produk mana yang sesuai dengan kebutuhan. Menurut Tjiptono (2012) produk adalah segala sesuatu yang dapat ditawarkan produsen untuk diperhatikan, diminta, dicari, dibeli, digunakan atau dikonsumsi pasar sebagai pemenuhan kebutuhan atau keinginan pasar yang bersangkutan.

Untuk mengukur kualitas produk menurut Tjiptono (2012), yaitu: 
1. Kinerja (performance), berhubungan dengan aspek fungional suatu produk dan karakteristik utama yang dipertimbangkan konsumen dalam membeli suatu produk.

2. Daya Tahan (durability), berkaitan dengan berapa lama atau umur suatu produk bertahan untuk terus digunakan dan sebelum produk tersebut harus diganti.

3. Kehandalan (reliability), berhubungan dengan kemungkinan suatu produk dapat menjalankan fungsinya dengan memuaskan atau tidak pada periode waktu tertentu. Semakin kecil kemungkinan terjadinya kerusakan maka produk tersebut dapat diandalkan.

4. Kesesuaian dengan spesifikasi (conformance to specifications) berhubungan dengan kesesuaian terhadap spesifikasi yang telah ditetapkan dan memenuhi standar sesuai ketentuan yang ada.

5. Keistimewaan (features), Berhubungan dengan karakteristik produk yang dirancang untuk menyempurnakan fungsi atau menambah ketertarikan terhadap produk.

6. Keindahan (aesthethic), yaitu daya tarik produk terhadap panca indera, misalkan bentuk fisik, model atau desain yang artistik, warna dan sebagainya.

\section{Gaya hidup}

Gaya hidup menurut Kotler dan Keller (2016) adalah pola hidup seseorang di dunia yang diekspresikan dalam aktivitas, minat, dan opininya. Gaya hidup menggambarkan keseluruhan diri seseorang dalam berinteraksi dengan lingkungannya. Sedangkan menurut Minor dan Mowen (2012) gaya hidup menunjukkan bagaimana seseorang hidup, bagaimana membelanjakan uangnya, dan bagaimana mengalokasikan waktu. Gaya hidup mencerminkan keseluruhan pribadi yang berinteraksi dengan lingkungan. Sedangkan menurut Setiadi (2013), Gaya hidup secara luas didefinisikan sebagai gaya hidup yang diidentifikasikan oleh bagaimana orang menghabiskan waktu mereka (aktivitas) apa yang mereka anggap penting dalam lingkungannya (ketertarikan), dan apa yang mereka pikirkan tentang diri mereka sendiri dan juga dunia disekitarnya (pendapat). Gaya hidup suatu masyarakat akan berbeda dengan masyarakat yang lainnya. Bahkan, dari masa ke masa gaya hidup suatu individu atau kelompok masyarakat tertentu akan bergerak dinamis. Gaya hidup menggambarkan keseluruhan pribadi yang yang berinteraksi dengan lingkunganya. Namun demikian, gaya hidup tidak cepat berubah sehingga pada kurun waktu tertentu gaya hidup relatif permanen.

Menurut Mowen dan Minor (2011) mengklasifikasikan gaya hidup berdasarkan tipologi values and lifestyle (VALS)sebagai berikut:

1. Actualizes, orang dengan pendapatan paling tinggi dengan demikian banyak sumber daya yang ada mereka sertakan dalam suatu atau semua orientasi diri.

2. Fulfilled, orang profesional yang matang, bertanggung jawab, dan berpendidikan tinggi. Mereka berpendapatan tinggi tetapi termasuk konsumen yang praktis dan berorientasi pada nilai.

3. Believers, konsumen konservatif, kehidupan mereka berpusat pada keluarga, agama, masyarakat dan bangsa.

4. Achievers, orang-orang yang sukses, berorientasi pada pekerjaan, konservatif dalam politik yang paling mendapatkan kepuasan dari pekerjaan dan keluarga mereka. Mereka menghargai otoritas dan status quo, serta menyukai produk dan jasa terkenal yang memamerkan kesukaan mereka.

5. Strivers, orang-orang dengan nilai-nilai yang serupa dengan achievers tetapi sumberdaya ekonomi, sosial dan psokologisnya lebih sedikit.

6. Experiences, u orang yang berkeinginan besar untuk menyukai hal-hal baru.

7. Makers, orang yang suka mempengaruhi lingkungan mereka dengan cara yang praktis. 
8. Strugglers, orang yang berpenghasilan rendah dan terlalu sedikit sumber dayanya untuk dimasukkan ke dalam orientasi konsumen yang manapun dengan segala keterbatasannya, mereka cenderung menjadi konsumen yang loyal pada merek.

\section{Pengetahuan Produk}

Menurut Sumarwan (2003) pengetahuan produk merupakan kumpulan berbagai informasi mengenai produk. Pengetahuan ini meliputi kategori produk, merek, terminologi produk, atribut, atau fitur produk, harga produk dan kepercayaan mengenai produk. Konsumen memiliki pengetahuan tentang produk yang berbeda-beda, ada yang mencari tahu info dengan datang langsung ke sumbernya, dan ada pula yang mencari tahu info dari sekitarnya. Menurut Brucks (1985) dalam Khosrozadeh (2011) menyatakan bahwa pengetahuan produk didasarkan pada ingatan atau pengetahuan yang diketahui dari konsumen. Pengetahuan produk memiliki peran yang penting dalam meneliti tentang perilaku pembelian suatu produk. Konsumen perlu mengetahui karakteristik suatu produk. Pengetahuan produk akan menjadi sumber bagi konsumen untuk terciptanya rasa percaya pada produk.

Lin \& Lin (2007) mengukur product knowledge dapat dengan menggunakan tiga cara yaitu:

1. Subjective knowledge, merupakan merupakan tingkat pengertian konsumen terhadap suatu produk sering disebut menilai pengetahuan sendiri.

2. Objective knowledge, yaitu tingkat dan jenis pengetahuan produk yang benar benar tersimpan dalam memori konsumen, disebut juga pengetahuan aktual (actual knowledge).

3. Experience-based knowledge, merupakan pengalaman sebelumnya dari pembelian atau penggunaan produk.

\section{Pengaruh Kualitas Produk terhadap Proses Keputusan Pembelian}

Menurut Kotler dan Keller (2016) kualitas produk adalah totalitas fitur dan karakteristik produk atau jasa yang bergantung pada kemampuannya untuk memuaskan kebutuhan konsumen yang dinyatakan atau tersirat. Kualitas produk dengan keputusan pembelian adalah dua hal yang saling berhubungan Semakin baik kualitas produk yang ditawarkan maka semakin meningkatkan keputusan pembelian. kualitas produk dengan keputusan pembelian adalah dua hal yang saling berhubungan. Penelitian yang dilakukan Dewi dan Prabowo (2018), Sari dkk (2018) menyatakan bahwa kualitas produk berpengaruh positif dan signifikan terhadap proses keputusan pembelian.semakin baik kualitas produk, maka akan semakin meningkatkan proses keputusan pembelian konsumen. Berdasarkan uraian diatas maka dapat dirumuskan hipotesis sebagai berikut:

H1: Kualitas Produk Berpengaruh Positif Terhadap Proses Keputusan Pembelian

\section{Pengaruh Gaya Hidup Terhadap Proses Keputusan Pembelian}

Gaya hidup menurut Kotler dan Keller (2016) adalah pola hidup seseorang di dunia yang diekspresikan dalam aktivitas, minat, dan opininya. Gaya hidup menggambarkan keseluruhan diri seseorang dalam berinteraksi dengan lingkungannya. Gaya hidup konsumen dengan berbagai macam aktivitas, minat dan opininya tentu akan memberi dampak pada pola hidup konsumen. Konsumen dengan pola teratur tentu akan selektif dalam memilih produk untuk digunakan sesuai kebutuhanya. Penelitian yang dilakukan oleh Mokoagouw (2016) dan Maharani (2018) menyatakan gaya hidup berpengaruh terhadap keputusan pembelian. Semakin meningkatnya gaya hidup konsumen, maka akan semakin meningkat pula keputusan pembelian yang dilakukan konsumen. Berdasarkan uraian diatas maka dapat dirumuskan hipotesis sebagai berikut: 


\section{$\mathbf{H}_{2}$ : Gaya Hidup Berpengaruh Positif Terhadap Proses Keputusan Pembelian}

\section{Pengaruh Pengetahuan Produk Terhadap Proses Keputusan Pembelian}

Pengetahuan produk menurut Sumarwan (2003) merupakan kumpulan berbagai informasi mengenai produk. Pengetahuan ini meliputi kategori produk, merek, terminologi produk, atribut atau fitur produk, harga produk dan kepercayaan mengenai produk. Pengetahuan produk memiliki peran yang penting dalam meneliti tentang perilaku pembelian suatu produk. Konsumen perlu mengetahui karakteristik suatu produk. Pengetahuan produk akan menjadi sumber bagi konsumen untuk terciptanya rasa percaya pada produk.Penelitian yang dilakukan oleh Shirin dan Kambiz (2011), Yoesmanam (2015), dan Novizal dan Rizal (2020) menyatakan bahwa pengetahuan produk berpengaruh positif dan signifikan terhadap keputusan pembelian. Dengan adanya pengetahuan tentang produk, konsumen akan mengetahui dan percaya bahwa produk yang dikonsumsi bermanfaat dalam memenuhi kebutuhan sehingga konsumen yang memiliki pengetahuan tentang produk tersebut akan melakukan proses keputusan pembelian ulang. Berdasarkan uraian diatas maka dapat dirumuskan hipotesis sebagai berikut:

$\mathbf{H}_{3}$ : Pengetahuan Produk Berpengaruh Positif Terhadap Proses Keputusan Pembelian

\section{Model Grafis}

Adapun model penelitian yang menggambarkan konsep hubungan antara varibel (X) dengan variabel (Y). Variabel bebas tersebut dalam penelitian ini yaitu Kualitas Produk (X1), Gaya Hidup (X2), dan Pengetahuan Produk (X3) yang berpengaruh terhadap variabel dependen yaitu Proses Kepuasan Pembelian (Y) adalah sebagai berikut:

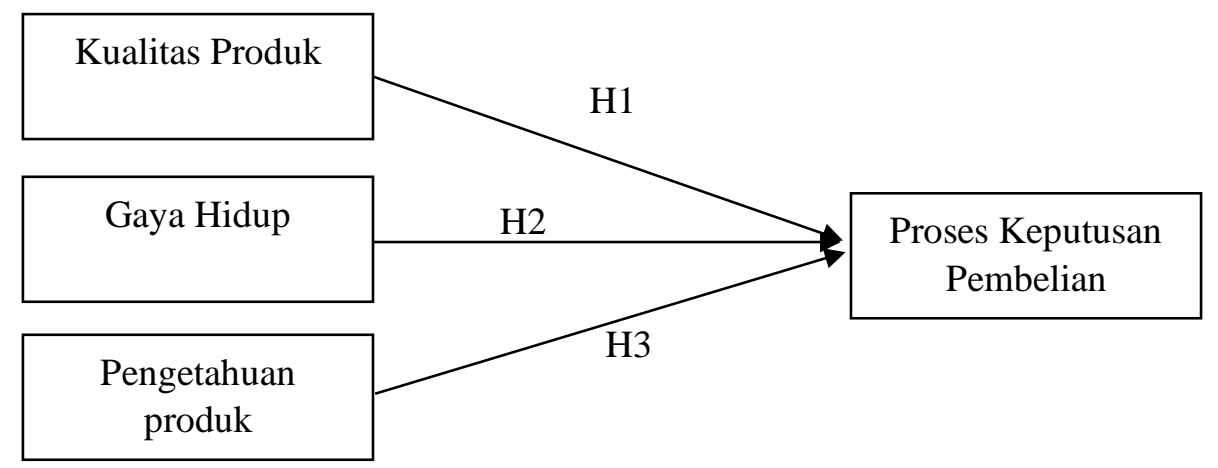

Gambar 2. Kerangka Penelitian

\section{Metode Penelitian}

Populasi dalam penelitian ini merupakan konsumen pembeli dan pengguna sepeda lipat yang ada di Kota Semarang. Penelitian dilakukan pada bulan Nopember sampai dengan Desember 2020. Pengambilan sampel dalam penelitian ini menggunakan Non-Probablity Sampling yaitu purposive sampling dimana pengambilan sampel didasarkan pada kriteria yang ditetapkan peneliti. Kriteria yang ditetapkan peneliti adalah konsumen yang membeli dan sebagai pengguna sepeda lipat, minimal berusia 17 tahun dan bersedia memberikan informasi yang dibutuhkan. Karena jumlah populasi dalam penelitian ini tidak diketahui secara pasti, maka penentuan jumlah sampel yang digunakan menggunakan rumus sebagai berikut:

$$
\boldsymbol{n}=\frac{Z^{2}}{4(m o e)^{2}}
$$




$$
n=\frac{1.96^{2}}{4(0.1)^{2}}=96,04
$$

Keterangan:

$\mathrm{n} \quad=$ Jumlah sampel

$\mathrm{Z} \quad=$ Tingkat keyakinan yang dalam penentuan sampel $90 \%=1,96$

Moe = Margin of error atau kesalahan maksimum yang bisa ditoleransi.

Pada penelitian ini digunakan $10 \%$ agar jumlah sampel yang dihasilkan tidak terlalu banyak.

Dengan dasar tersebut maka dapat dilihat ukuran sampel minimal yang harus dicapai dalam penelitian ini adalah sebanyak 96,04 orang, atau dibulatkan sebesar 100 orang atau responden. Teknik pengumpulan data yang digunakan dalam penelitian ini melalui penyebaran kuesioner. Penyebaran kuisioner ini dilakukan dengan cara memberikan link google form yang berisi pertanyaan kepada responden. Metode pengumpulan data yang digunakan metode angket atau questionnaire dengan mengunakan skala Likert 1-5.

Indikator variabel kualitas produk menggunakan item pertanyaan Tjiptono (2016) berupa kinerja, daya tahan, kehandalan, kesesuaian dengan spesifikasi, keistimewaan, keindahan; Indikator variabel Gaya Hidup berupa aktivitas, minat, pendapat tentang sepeda lipat (Setiadi, 2010); Indikator variabel pengetahuan produk berupa pengetahuan yang dirasakan, objektif, berbasis pengalaman (Lin \& Lin, 2007); Indikator variabel Proses Keputusan Pembelian mengetahui masalah, menemukan informasi produk yang sesuai, memilih produk dengan mengevaluasi terlebih dahulu, memutuskan membeli, perilaku pasca pembelian (Kotler dan Keller, 2016).

Teknik mengolah data dilakukan menggunakan analisis deskriptif dan analisis statistika. Analisis deskriptif untuk mengetahui gambaran umum responden, sedangkan analisis statistika digunakan untuk menjawab pertanyaan penelitian dengan cara menganalisis dan menguji model empirik dengan regresi berganda menggunakan bantuan software SPSS 24,00

\section{Pembahasan}

Responden pada penelitian ini adalah konsumen atau pengguna sepeda lipat yang ada di Kota Semarang dengan jumlah responden sebanyak 100 responden. Kuisioner yang dijadikan sebagai sampel penelitian, melalui daftar pertanyaan di dapat profil tentang responden meliputi nama responden, usia, jenis kelamin, dan pekerjaan. Sebagian besar responden adalah Laki-laki yang berjumlah 58 responden atau 58\%, hal ini menunjukan bahwa laki-laki lebih menyukai sepeda lipat daripada perempuan karena sepeda lipat bisa menjunjang aktivitasnya. Usia responden terbesar berada pada usia 25-32 tahun sebanyak 59 responden (59\%) karena umumnya responden masih kalangan muda sehingga tren bersepeda sangat cepat digemari. Sebagian besar pengguna sepeda lipat berdasarkan pekerjaan adalah pelajar/Mahasiswa sebanyak $41(41 \%)$ karena pelajar dan mahasiswa mudah mengikuti trend bersepeda dengan menggunakan sepeda lipat.

\section{Uji Instrumen}

\section{Uji Validitas}

Uji validitas dilakukan dengan teknik analisis faktor yaitu menguji apakah maisngmasing butir pertanyaan dapat mengkonfirmasi sebuah faktor atau variabel dengan kriteria nilai Kaiser Meyer-Olkin Measure of Sampling Adequancy (KMO) > 0,5 (Ghozali, 2013). Jika masing-masing butir pertanyaan merupakan indikator pengukuran variabel maka akan 
memiliki loading faktor > 0,4 maka sampel dalam penelitian dianggap cukup valid untuk dianalisis lebih lanjut. Uji validitas dari variabel kualitas produk, memiliki nilai $\mathrm{KMO}=0.789$; variabel gaya hidup memiliki nilai $\mathrm{KMO}=0,641$; variabel pengetahuan produk memiliki nilai $\mathrm{KMO}=0,631$; variabel proses keputusan pembelian memiliki nilai $\mathrm{KMO}=0,720$. Hal ini menunjukkan bahwa jumlah sampel yang diuji sudah memenuhi kriteria kecukupan sampel. Semua indikator dinyatakan valid. Hal ini terlihat dari loading factor (component matrix) variabel kualitas produk mempunyai nilai 0.651 sampai dengan 0.783 , variabel gaya hidup mempunyai nilai 0.749 sampai dengan 0.855 , variabel pengetahuan produk mempunyai nilai 0.763 sampai dengan 0.857 , variabel proses keputusan pembelian memiliki nilai 0.618 sampai dengan 0.802 ; masing-masing butir pernyataan besarnya lebih dari 0,4.

\section{Uji Reliabilitas}

Uji reliabilitas adalah indeks yang menunjukan suatu alat pengukur dapat dipercaya atau diandalkan. Variabel dikatakan handal atau reliable jika nilai Cronbach's Alpha > 0,7. Dari hasil penelitian data yang telah dilakukan terlihat bahwa nilai Cronbach Alpha dari masing-masing variabel lebih dari 0,7 sehingga dapat disimpulkan bahwa instrument yang digunakan dalam penelitian ini memiliki tingkat reliabilitas yang memadai. Hasil pengujian menunjukkan besarnya nilai Cronbach Alpha pada variabel Kualitas Produk adalah sebesar $0,828(>0,7)$, artinya bahwa seluruh instrument variabel tersebut adalah reliable. Besarnya nilai Cronbach Alpha pada variabel gaya hidup adalah sebesar 0,712 (>0,7); variabel pengetahuan produk adalah sebesar $0,703(>0,7)$; artinya bahwa seluruh instrument variabel tersebut adalah reliable. Besarnya nilai Cronbach Alpha variabel proses keputusan pembelian adalah sebesar 0,766 (>0,7), artinya bahwa seluruh instrument variabel tersebut adalah reliable.

\section{Uji Model}

\section{Koefisien Determinasi (Adjusted $\mathbf{R}^{2}$ )}

Koefisien determinasi $\left(\mathrm{R}^{2}\right)$ pada intinya mengukur seberapa jauh kemampuan model pada variabel independen (X) dalam menerangkan variasi variabel dependen (Y). Nilai koefisien determinasi dilihat dari nilai adjusted $\mathrm{R}$ square adalah 0,732 atau 73,2\% variasi proses keputusan pembelian dapat dijelaskan oleh variasi dari variabel independen kualitas produk, gaya hidup dan pengetahuan produk sedangkan sisanya 26,8\% dipengaruhi oleh variabel lainnya yang tidak diteliti dalam penelitian ini.

\section{Uji F}

Uji $\mathrm{F}$ digunakan untuk menunjukkan apakah semua variabel independen atau bebas yang dimasukkan dalam model mempunyai pengaruh secara bersama-sama terhadap variabel dependen atau terikat. Jika hasil pengujian menunjukkan nilai signifikan < alpha (menggunakan signifikansi level 0,05) maka H0 ditolak dan Ha diterima, yang berarti secara bersama-sama variabel independen mempengaruhi variabel dependen. Hasil penelitian diketahui nilai F hitung sebesar 91,139 dengan tingkat signifikan sebesar 0,000 maka modelnya bisa diterima dan dapat dikatakan bahwa kualitas produk, gaya hidup dan pengetahuan produk secara bersama sama berpengaruh terhadap proses keputusan pembelian.

\section{Analisis Regresi Linier Berganda}

Peneliti menggunakan program SPSS 24,00 for windows antara variabel Kualitas Produk (X1), Gaya Hidup (X2), Pengetahuan Produk (X3) terhadap Keputusan Pembelian (Y) diperoleh hasil analisis yang terangkum sebagai berikut: 
INOBIS: Jurnal Inovasi Bisnis dan Manajemen Indonesia

Volume 04, Nomor 03, Juni 2021

Yusuf Bagus Prakosa, Endang Tjahjaningsih

Tabel 2. Hasil Analisis Regresi Linear Berganda

\begin{tabular}{|c|c|c|c|c|c|c|}
\hline \multirow{2}{*}{ Variabel } & \multirow{2}{*}{$\begin{array}{c}\text { Adjusted } \\
\mathbf{R}^{2}\end{array}$} & \multicolumn{2}{|c|}{ Uji F } & \multicolumn{2}{|c|}{ Uji t } & \multirow{2}{*}{ Keterangan } \\
\hline & & $\mathbf{F}$ & Sig & Beta & Sig & \\
\hline Kualitas Produk (X1) & \multirow{3}{*}{0,732} & \multirow{3}{*}{91,139} & \multirow{3}{*}{0,000} & 0,652 & 0,000 & H1 Diterima \\
\hline Gaya Hidup (X2) & & & & 0,277 & 0,000 & H2 Diterima \\
\hline Pengetahuan Produk (X3) & & & & 0,132 & 0,013 & H3 Diterima \\
\hline
\end{tabular}

Sumber : Data primer yang diolah 2020

Hasil persamaan regresi linier berganda ditunjukkan pada persamaan:

$$
\mathrm{Y}=0,652(\mathrm{X} 1)+0,277(\mathrm{X} 2)+0,132(\mathrm{X} 3)+\mathrm{e}
$$

Berdasarkan hasil persamaan regresi linear berganda di atas dapat diketahui :

1. Koefisien regresi $\beta$ variabel kualitas produk 0,625 berarti kualitas produk berpengaruh terhdap proses keputusan pembelian.

2. Koefisien regresi $\beta$ variabel gaya hidup 0,277 berarti gaya hidup berpengaruh terhdap proses keputusan pembelian.

3. Koefisien regresi $\beta$ variabel pengetahuan produk 0,132 berarti pengetahuan produk berpengaruh terhdap proses keputusan pembelian.

\section{Uji Hipotesis}

Hipotesis pertama menyatakan bahwa kualitas produk (X1) berpengaruh terhadap keputusan pembelian (Y). Diketahui variabel kualitas produk memperoleh nilai standar koefisien (beta) sebesar 0,652 dengan nilai signifikansi 0,000 maka hal ini membuktikkan bahwa H1 diterima. Dengan demikian dapat disimpulkan bahwa variabel kualitas produk berpengaruh positif terhadap proses keputusan pembelian. Berdasarkan hasil uji hipotesis 1 menunjukan kualitas produk berpengaruh positif terhadap proses keputusan pembelian sepeda lipat. Semakin baik baik kualitas produk maka akan semakin tinggi keputusan pembelian sepeda lipat. kualitas produk adalah totalitas fitur dan karakteristik produk atau jasa yang bergantung pada kemampuanya untuk memuaskan kebutuhan yang dinyatakan atau tersirat. Hasil penelitian ini juga sesuai dengan hasil penelitian terdahulu yang menyatakan bahwa kualitas produk berpengaruh positif terhadap proses keputusan pembelian. Hasil penelitian ini didukung oleh Sari dkk (2018) dan penelitian yang dilakukan oleh Mokoagouw (2016) yang menyatakan bahwa kualitas produk mempunyai pengaruh positif dan signifikan terhadap proses keputusan pembelian.

Hipotesis kedua menyatakan bahwa gaya hidup (X2) berpengaruh terhadap keputusan pembelian (Y). Diketahui variabel gaya hidup memperoleh nilai standar koefisien (beta) sebesar 0,277 dengan nilai signifikansi 0,000 maka hal ini membuktikkan bahwa $\mathrm{H} 2$ diterima. Dengan demikian dapat disimpulkan bahwa variabel gaya hidup berpengaruh positif terhadap proses keputusan pembelian. Berdasarkan hasil uji hipotesis 2 menunjukan gaya hidup berpengaruh positif terhadap proses keputusan pembelian sepeda lipat. Semakin baik gaya hidup bersepeda menggunakan sepeda lipat maka semakin baik juga tingkat proses keputusan pembelian. Gaya adalah pola hidup seseorang di dunia yang diekspresikan dalam aktivitas, minat, dan opininya. Hasil penelitian ini juga sesuai dengan hasil penelitian terdahulu yang menyatakan bahwa gaya hidup berpengaruh positif terhadap proses keputusan pembelian. Hasil penelitian ini didukung oleh Mahanani (2018) dan penelitian yang dilakukan oleh Nia dan Prabowo (2018) yang menyatakan bahwa gaya hidup mempunyai pengaruh positif dan signifikan terhadap proses keputusan pembelian. 
Hipotesis ketiga menyatakan bahwa pengetahuan produk (X3) berpengaruh terhadap keputusan pembelian (Y). Diketahui variabel pengetahuan produk memperoleh nilai standar koefisien (beta) sebesar 0,132 dengan nilai signifikansi 0,013 maka hal ini membuktikkan bahwa H3 diterima. Dengan demikian dapat disimpulkan bahwa variabel pengetahuan produk berpengaruh positif terhadap proses keputusan pembelian. Berdasarkan hasil uji hipotesis 3 menunjukan pengetahuan produk berpengaruh positif terhadap proses keputusan pembelian sepeda lipat. Semakin baik pengetahuan produk maka semakin tinggi tingkat keputusan pembelian sepeda lipat. Pengetahuan produk adalah kumpulan berbagai informasi mengenai produk. Pengetahuan ini meliputi kategori produk, merek, terminologi produk, atribut atau fitur produk, harga produk dan kepercayaan mengenai produk. Hasil penelitian ini juga sesuai dengan hasil penelitian terdahulu yang menyatakan bahwa pengetahuan produk berpengaruh positif terhadap proses keputusan pembelian. Hasil penelitian ini didukung oleh Yoesmanam (2015) dan penelitian yang dilakukan oleh Novizal dan Rivai (2020) yang menyatakan bahwa pengetahuan produk mempunyai pengaruh positif dan signifikan terhadap proses keputusan pembelian.

\section{Kesimpulan}

Kualitas produk memiliki pengaruh positif terhadap proses keputusan pembelian sepeda lipat di Kota Semarang. Semakin baik kualitas produk maka semakin tinggi juga tingkat proses keputusan pembelian. Demikian sebaliknya jika kualitas produk rendah maka semakin rendah juga tingkat proses keputusan pembelian.Gaya hidup memiliki pengaruh positif terhadap proses keputusan pembelian sepeda lipat di Kota Semarang. Semakin baik gaya hidup konsumen maka semakin tinggi juga tingkat proses keputusan pembelian. Demikian sebaliknya jika gaya hidup konsumen rendah maka semakin rendah juga tingkat proses keputusan pembelian. Pengetahuan produk memiliki pengaruh positif terhadap proses keputusan pembelian sepeda lipat di Kota Semarang. Semakin baik pengetahuan produk konsumen maka semakin tinggi juga tingkat proses keputusan pembelian. Demikian sebaliknya jika pengetahuan produk konsumen rendah maka semakin rendah juga tingkat proses keputusan pembelian.

\section{Saran dan Agenda Penelitian Selanjutnya}

Variabel kualitas produk, gaya hidup, dan pengetahuan produk terbukti berpengaruh terhadap proses keputusan pembelian maka perlu mendapatkan perhatian khusus untuk dapat meningkatkan volume penjualan pada perusahaan perakitan sepeda lipat. Hasil penelitian ini juga dapat digunakan bagi peneliti yang ingin melakukan penelitian tentang pengaruh kualitas produk, gaya hidup, dan pengetahuan produk terhadap proses keputusan pembelian. penelitian selanjutnya diharapkan bisa lebih menjelaskan proses keputusan pembelian dengan menambah variabel bebas seperti kepercayaan, word of mouth dan niat beli ulang

\section{Daftar Pustaka}

Brucks, M. (1985) “The Effect of Product Class Knowledge on Information Search Behavior”, Journal of Consumer Research 12 (1), 1-16.

Sari, Diana; Kristina, Tjahjaningsih (2018) "Pengaruh Kualitas Produk, Persepsi Harga, Promosi dan Lokasi terhadap Keputusan Pembelian Produk Kapur Barus "BAGUS (Studi pada konsumen Giant BSB Semarang), Prosiding SENDI_U 2018, ISBN: 978979-3649-99-3 
Euis, Soliha; Wifky (2017) Pengaruh Kualitas Produk,Citra Merek, Persepsi Harga dan Keputusan Pembelian Konsumen Honda Mobilio. Prosiding Seminar Nasional Multi Disiplin Ilmu \& Call For Papers Unisbank Ke-3. ISBN: 9-789-7936-499-93

Ghozali, Imam (2013) Analisis Aplikasi Multivariat dengan Program IBM SPSS, Universitas Diponegoro, Semarang.

Haramaini, Nadwatul, N. Rachma; Slamet (2019) "Pengaruh Promosi, Harga, Citra Merek, dan Kualitas Produk Terhadap Keputusan Pembelian (Studi Kasus Pada Toko Donatello Jl. Kawi Malang)", $e$-Jurnal Riset Manajemen, Fakultas Ekonomi Unisma.

Heidarzadeh, Kambiz Hanzaee; Shirin. (2011) "The Effect of the Country of Origin Image, Product Knowledge and Product Involvement on Information Search and Purchase Intention", Journal Middle-East Journal of Scientific Research 8 (3): 625-636, 2011 ISSN 1990-9233

Kotler, Philip; Amstrong, Gerry (2014). Dasar-Dasar Pemasaran. Jilid 1. Jakarta: PT. Gramedia Pustaka Utama.

Kotler, Philip; Keller (2016) Manajemen Pemasaran, Jilid I, Erlangga, Jakarta.

Lin, Nan Hong \& Lin, Bih Shya, (2007) The Effect of Brand Image and Product Knowledge on Purchase Intention Moderated by Price Discount., Journal of International Management Studies, August 2007.

Mahanani, Estu (2018) "Pengaruh Citra Merek, Kualitas Produk, Harga, dan Gaya Hidup terhadap Keputusan Pembelian Produk Matahari Mall", Jurnal IKRAITHHUMANIORA, Vol. 2, No. 2 Maret 2018.

Mokoagouw, Milly Lingkan (2016) "Pengaruh Gaya Hidup, Harga, Kualitas Produk Terhadap Keputusan Pembelian Handphone Samsung di Samsung Mobile IT Center Manado", Jurnal Berkala Ilmiah Efisiensi, Volume 16 No. 01 Tahun 2016.

Mowen, J. C; Minor, M. (2012), Perilaku Konsumen, PT. Erlangga, Jakarta.

Novizal, Guntur; Rizal, Alimuddin (2020), "Pengaruh Product Knowledge dan Persepsi Harga terhadap Keputusan Pembelian dengan Brand Image sebagai variabel Moderasi (Studi pada konsumen mobil Wuling di Dealer Wuling Semarang"), Proceeding SENDIU 2020 ISBN:978-979-3649-72-6

Osly Usman; Galih Prihastomo (2019), "The Effect of Product Quality, Price, Promotion, and Lifestyle on Purchase Decisions to Drink The Coffee". Jurnal Online diakses 22 September 2020 pada https://www.semanticscholar.org/paper/The-Effect-of-ProductQuality\%2C-Price\%2C-Promotion\%2C-on-PrihastomoUsman/110d8c99a $026254 d c 7 e 616 c 30 f d 9 b 46 a b 8146 f 5$.

Peter, P, J, \& Olson, Jerry, C. (2014) Costumer Behavior, Jilid 2, (alih bahasa Damos Sihombing). Erlangga, Jakarta.

Prabowo, Rokh Eddy; Nia, Safitri. (2018) "Pengaruh Kualitas Produk, Harga, Promosi, dan Gaya Hidup terhadap Keputusan Pembelian minuman isotonik (Studi pada konsumen minuman isotonik di Kota Semarang)", Prosiding SENDI_U 2018. ISBN: 978-9793649-99-3 
Schiffman, L, G. dan, L. L. Kanuk (2014). Persepsi kualitas, Consumer Behavior, Perason Prestice Hall, New Jersey.

Setiadi, N. (2003). Konsep Dan Implikasi Untuk Strategi dan Penelitian Pemasaran, Kencana, Jakarta.

Sumarwan, Ujang. (2011). Perilaku Konsumen Teori dan Penerapannya dalam Pemasaran, Edisi Kedua. Bogor: Ghalia Indonesia.

Tjiptono, Fandy. (2016) Strategi Pemasaran, Andi, Yogyakarta.

Umboh, Sisilia Oktavia, Altje Tumbel, dan Djurwati Soepeno (2015) “Analisis Kualitas Produk, Brand Image, dan Life Style terhadap Keputusan Pembelian pakaian wanita di Mississipi Manado Town Square", Jurnal EMBA Vol.3 No.1 Maret 2015, Hal. 1096-1105. ISSN 2303-1174

Yoesmanam, Indarti Candra (2015) "Pengaruh Pengetahuan Produk dan Presepsi Kualitas Produk terhadap Keputusan Pembelian pada Kosmetik Organik", Jurnal Bisnis dan Manajemen Volume 7 No. 2 Februari 2015.

www.https://iprice.co.id/

www.topbrand-award.com 